\title{
AN EMPIRICAL INVESTIGATION OF THE EFFECTS OF ETHICAL CLIMATES ON ORGANIZATIONAL CORRUPTION
}

\author{
Agata Stachowicz-Stanusch $^{1}$, Aditya Simha ${ }^{2}$ \\ ${ }^{1}$ Department of Management and Marketing, \\ Silesian University of Technology, Roosevelta 26, Zabrze, Poland \\ ${ }^{2}$ Department of Management, \\ University of Wisconsin - Whitewater, Whitewater, WI 53190, USA \\ E-mails: 1astachowicz@polsl.pl; ${ }^{2}$ simhaa@uww.edu (corresponding author)
}

Received 22 December 2011; accepted 16 October 2012

\begin{abstract}
This study investigates the effects of ethical climates on organizational corruption. Data from 200 employees from seven hospitals in Poland was used to test the specific relationships between the five empirically occurring ethical climate types (i.e. caring, instrumental, independence, law and code, and rules) and organizational corruption. Law and code climates were negatively associated with organizational corruption, while instrumental and caring climates were positively associated with organizational corruption.
\end{abstract}

Keywords: ethical climates, organizational corruption, Polish context, multiple regression, instrumental, law and code, caring.

Reference to this paper should be made as follows: Stachowicz-Stanusch, A.; Simha, A. 2013. An empirical investigation of the effects of ethical climates on organizational corruption, Journal of Business Economics and Management 14(Supplement 1): S433-S446.

JEL Classification: M10. M14. M16.

\section{Introduction}

Corruption has become endemic in a worldwide organizational context. The list of organizational offenders in terms of corruption are prominent - Enron, 1Global Crossing, Adelphia, Quest, Tyco, and WorldCom - are but a few of the prominent organizations that have engaged in corruption (Ashforth et al. 2008: 670). The World Bank has suggested that corruption is a huge stumbling block for economic and social development (Aguilera, Vadera 2008; United Nations 2002, 2008; World Bank 2000), and Kayes (2006) also suggests that the growing number of organizational scandals has made the public aware about corruption. The very recent world crisis has also been a resultant of corrupt financial practices (Teather 2009; Voliotis 2011; Watkins 2003), which only goes to show that corruption is very much prevalent in a global context.

This growing epidemic of corruption has reduced confidence and trust in organizations and leaders (Ashforth et al. 2008; Colvin 2004; Nocera 2002). It also appears that corruption has existed since ancient times (Aguilera, Vadera 2008). Several studies have 
documented the negative effects of corruption - these negative effects range from economic development to different measures of economic welfare (Dumludag 2009; Mauro 1995; Ogrean et al. 2008; Rose-Ackerman 2002; Rivera-Batiz 2001; Shleifer, Vishny 1993; Venard 2009).

As one can infer from the evidence, studying the causes and consequences of organizational corruption is quite an important cause! Aguilera and Vadera (2008) and Pelletier and Bligh (2008) state that research in organizational corruption is fairly recent, as most research efforts on corruption seem to have delved into political science and political philosophy, rather than organizational corruption.

One theory that could be useful to study the causes of organizational corruption is ethical climate theory (ECT) (Victor, Cullen 1987, 1988). Ethical climates play an important role in developing the context in which employees operate (Trevino et al. 1998), and it is likely that ethical climates will be related with organizational corruption.

In this paper, we provide a literature review of organizational corruption, a theoretical background and hypotheses which are based on ECT. We present a methodology section followed by the results and discussion. Our main purpose in this paper is to explore the relationship between ethical climate types and organizational corruption.

\section{Organizational corruption}

Corruption and organizational corruption have been defined many different ways (Apaydin, Balci 2011; Venard 2009); however, the definitions proposed by Aguilera and Vadera (2008) are considered standard. Corruption is defined as an "abuse of authority for personal benefit" (p. 433) and organizational corruption is defined as "the crime that is committed by the use of authority within organizations for personal gain" (p. 433). These two definitions of corruption emerged from previous definitions propounded by other scholars - for instance, Ashforth and Anand (2003) defined organizational corruption as the "misuse of authority for personal, subunit, and/or organizational gain" (p. 2). Other definitions of corruption have also been presented by Habib and Zurawicki (2002); Luo (2004); Robertson and Watson (2004); Rodriguez et al. (2005); Sherman (1980); Theobald (1990); and Voliotis, (2011). In this paper, we will be relying on the framework provided by Aguilera and Vadera (2008) to define and work with the organizational corruption construct.

Luo (2004) provided a model of organizational corruption that related the organization's environment to deviant behaviors within the organization, and then also addressed the consequences and potential anti-corruption actions. Aguilera and Vadera (2008) expanded Luo's framework and offered their version of an antecedent-effect framework. Aguilera and Vadera (2008) also connected the opportunity-motivation-justification model of crime with organizational corruption. Their framework relies heavily on Weberian concepts of authority (Weber 2002), as well as on Sedikides and Brewer's (2001) classification of motives (individualistic, collectivistic, and relational). With these two concepts, Aguilera and Vadera (2008) also introduced the notion of justification (rationalization, socialization, and ritualism). 
Corruption is classified as either individualistic or collectivistic according to who accrues the benefits of corruption (Pinto et al. 2008; Voliotis 2011; Waite, Allen 2003). However, as both Ashforth et al. (2008) and Voliotis (2011) put it, organizational corruption is essentially meant to be studied in an interactionist way that transcends levels, and is instead multilevel in scope. Ethical climate theory has been used in multilevel studies earlier (e.g. Parboteeah, Kapp 2008; Parboteeah et al. 2005), and so it seems appropriate to study the effects of ethical climates on organizational commitment - thus meeting the interactionist approach that Ashforth et al. (2008) advocate. Now we present our theoretical background and layout our hypotheses.

\section{Theoretical background and hypotheses}

\subsection{Ethical climates}

Organizational climates have effects on many organizational variables (Martin, Cullen 2006; Simha, Cullen, 2012; Zukauskas, Vveinhardt 2011). Ethical climates are subsets of organizational work climates. Ethical climate theory was first proposed by Victor and Cullen $(1987,1988)$. Ethical climates refer to organizational practices and procedures that define what is considered right or wrong within an organization (Parboteeah, Kapp, 2008).

Victor and Cullen (1987, 1988) based their work off on Kohlberg's (1984) work on moral development and Schneider's (1983) work on sociocultural theories of organization. Their ECT framework consists of a two-dimensional model of ethical climate types, where one dimension is ethical philosophy and the other is a dimension based on the sociological theory of reference groups (Merton, 1968). The three ethical constructs are egoism, benevolence and principle. The other construct, locus of analysis, was categorized by Victor and Cullen (1988) as individual, local, and cosmopolitan. The crossing of these two criteria results in nine theoretical climate types which are as shown in figure 1.

From nine ethical climate types, research demonstrated that five ethical climate types are the most commonly occurring ones (Martin, Cullen 2006; Tsai, Huang 2008). These five ethical climate types are represented in figure 2.

\begin{tabular}{c|c|c|c|c|}
\multicolumn{1}{c|}{} & \multicolumn{4}{c|}{ LOCUS OF ANALYSIS } \\
\cline { 2 - 5 } & Individual & Local & Cosmopolitan \\
\hline \multirow{4}{*}{$\begin{array}{l}\text { Ethical } \\
\text { Theory }\end{array}$} & Benoism & Self-Interest & Company Profit & Efficiency \\
\cline { 2 - 5 } & Principle & $\begin{array}{c}\text { Personal } \\
\text { Morality }\end{array}$ & $\begin{array}{c}\text { Company rules and } \\
\text { procedures }\end{array}$ & $\begin{array}{c}\text { Laws and Professional } \\
\text { codes }\end{array}$ \\
\cline { 2 - 5 } & & Friendship & Team-Interest & Social-Responsibility \\
\hline
\end{tabular}

Fig. 1. Theoretical strata of ethical climate (Victor, Cullen 1987, 1988) 
LOCUS OF ANALYSIS

\begin{tabular}{|c|c|c|c|c|}
\hline & & Individual & Local & Cosmopolitan \\
\hline \multirow{3}{*}{ Ethical Theory } & Egoism & Instrumental & Instrumental & \\
\hline & Benevolence & Caring & Caring & \\
\hline & Principle & Independence & Rules & Law and code \\
\hline
\end{tabular}

Fig. 2. Five common empirical derivatives of ethical climate (Victor, Cullen 1987, 1988)

\section{Instrumental}

Employees perceiving instrumental ethical climates in their organizations tend to see their units as encouraging ethical decision-making from an egoistic perspective (Martin, Cullen 2006: 178). Self-interest promoting behavior even at the cost of potential detriment to others is prevalent in instrumental ethical climates. Evidence exists that suggests that instrumental climates are associated with unfavorable outcomes. For instance, Wimbush and Shepard (1994) said that in instrumental climates, decision-making is made so as to serve one's self-interest or personal benefit. Cullen et al. (2003) found that instrumental climates have negative associations with commitment, as did Tsai and Huang (2008). Similarly, Bulutlar and Öz (2009) found that instrumental climates were associated with elevated levels of workplace bullying. Deshpande (1996), Joseph and Deshpande (1997), and Tsai and Huang (2008) all found negative associations of instrumental climates with job satisfaction. In case of corruption as well, the self-interest criteria that is so prevalent in this type of climate may well allow corruption to flourish - especially since corruption is associated with self-interest and personal gain. This suggests that instrumental climates will be positively associated with organizational corruption.

H1: Instrumental climates are positively related to organizational corruption.

\section{Caring}

The caring construct emerges from benevolence theory - the essence of benevolence theory is that behaviors yielding in positives for the greatest number of constituents are encouraged. Individuals operating in caring climates perceive that decisions should be based on an overarching concern for others (Martin, Cullen 2006). Caring climates are found to be associated with a lot of beneficial and positive organizational outcomes for instance, Deshpande (1996), Joseph and Deshpande (1997), and Tsai and Huang (2008) found that caring climates were associated with elevated levels of job satisfaction. Cullen et al. (2003) and Tsai and Huang (2008) found that caring climates have positive associations with organizational commitment. Several other studies found positive outcomes associated with caring climates (Koh, Boo 2001; Parboteeah, Kapp 2008; Parboteeah et al. 2010; Sims, Keon 1997). This suggests that caring climates will be negatively associated with organizational corruption.

H2: Caring climates are negatively related to organizational corruption. 


\section{Independence}

The independence climate is associated with independence of thought and action. In these sorts of climates, individuals believe that they need to act on deeply held, personal moral convictions to make ethical decisions. Decision making in independence climates emphasizes personal moral beliefs with minimal regard for outside influences (Martin, Cullen 2006). These individual principles are determined through careful consideration (Martin, Cullen 2006; Schminke et al. 2005). The deciding factor for people's actions is based on one's personal moral beliefs (Tsai, Huang 2008), and on a similar note, Ambrose et al. (2008) found that individuals with a post-conventional level of cognitive moral development work in independence climates.

That suggests that corruption incidences are likely to be low in an independence climate, as principles of deontology and utilitarianism are likely to dictate actions and behaviors there. Independence climates have also been associated with a lot of positive organizational outcomes, such as elevated levels of commitment and satisfaction, reduced turnover intentions, and reduced workplace bullying (Bulutlar, Öz 2009; Cullen et al. 2003; Deshpande 1996; Joseph, Deshpande 1997; Parboteeah et al. 2010; Tsai, Huang 2008). This suggests that independence climates will be associated with low levels of organizational corruption.

H3: Independence climates are negatively related to organizational corruption.

\section{Law and code}

The principle ethical criterion is the main construct behind the law and code ethical climate. The law and code climate fosters the expectation that people operating under it have to adhere to codes and regulations of their profession or other external codes. This climate, just like the caring and independence climates, has been associated with a lot of positive outcomes, such as elevated levels of satisfaction, commitment, reduced turnover, and reduced bullying (Bulutlar, Öz 2009; Cullen et al. 2003; Deshpande 1996; Joseph, Deshpande 1997; Parboteeah et al. 2010; Tsai, Huang 2008). Since in this climate, principled decision-making based on verifiable external codes is emphasized, it seems likely that law and code climates will be negatively associated with organizational corruption.

H4: Law and code climates are negatively related to organizational corruption.

\section{Rules}

This particular climate is based on the construct defined as company rules and procedures. In the rules climate, organizational decisions are perceived as being guided by a strong and pervasive set of local rules and standards such as codes of conduct (Appelbaum et al. 2005; Aquino, Becker 2005; Liu et al. 2004; Martin, Cullen 2006; Simha, Cullen 2012). Rules climates too have been associated with positive outcomes such as elevated levels of satisfaction, commitment, and reduced turnover (Cullen et al. 2003; Deshpande 1996; Joseph, Deshpande 1997; Parboteeah et al. 2010; Tsai, Huang 2008). People operating under the rules climate know that there is a verifiable code of 
conduct within the organization, and therefore it seems likely that rules climates will be negatively associated with organizational corruption.

H5: Rules climates are negatively related to organizational corruption.

\section{Methods}

\subsection{Sample}

The sample was drawn from seven hospitals in Poland, and consisted of hospital administrators and management personnel. We translated all surveys into Polish first and then back-translated them into English to remove translation errors. After the survey was validated, we distributed 300 surveys in total, and received 200 completed and useable surveys back. Our useable response rate was 67 percent, and our sample was predominantly female (82\%). 62.5 percent of our respondents had at least a college degree, and the average years of experience they had was 25.29 years.

\subsection{Ethical climate}

We measured ethical climate by using the Ethical Climate Questionnaire (ECQ) first developed by Victor and Cullen $(1987,1988)$. In the ECQ, respondents are asked to act as observers reporting on organizational expectations, not on their personal beliefs or their affective evaluations of the climates. The complete version of the ECQ is available in Cullen et al. (1993). This particular scale has demonstrated excellent validity and reliability (Martin, Cullen 2006; Tsai , Huang 2008).

\subsection{Organizational corruption}

We measured organizational corruption by using an adapted version of the scale provided by Balci et al. (2012). In this scale, respondents are asked to report on the corruption prevalent in their organization.

\subsection{Control variables}

We collected responses to the following items in order to control for potential confounding effects on the perceptions of ethical climate and organizational trust: age, gender, education level, and years of work experience.

\subsection{Analytical procedures}

Similar to previous research (Parboteeah et al. 2005; Parboteeah, Kapp 2008), we conducted separate factor analyses on items reflecting ethical climates. Factors were then constructed using the appropriate items. The five factors that emerged corresponded to the five ethical climate types - the factor loadings and coefficient alphas of the ethical climate scales are presented in Table 1.

Even though, it may appear as though our scales have low Cronbach alphas (i.e. lower than 0.7 ), what we obtained is very similar to what was obtained by other researchers (Cullen et al. 2003; Tsai, Huang 2008). There exists evidence that states that Cronbach alphas are lower than 0.7 especially if the scale has lesser than 10 items (Pallant 2004; 
Wilson et al. 2008), so therefore the rule of thumb of 0.7 does not apply if scales have fewer than 10 items. Therefore, our scales can be considered reliable.

Similarly, a factor score was obtained for our measure of organizational corruption. Multiple regression analysis was the technique chosen by us to test Hypotheses 1 through 5 .

Table 1. Factor loadings and coefficient alpha for ethical climate

\begin{tabular}{|c|c|c|}
\hline Ethical climate types & $\begin{array}{c}\text { Factor } \\
\text { Loading }\end{array}$ & $\begin{array}{c}\text { Cronbachs } \\
\text { alpha }\end{array}$ \\
\hline \multicolumn{3}{|l|}{ Caring } \\
\hline $\begin{array}{l}\text { In this company, our major concern is always what is best for } \\
\text { the other person }\end{array}$ & 0.627 & \\
\hline Our major consideration is what is best for everyone in this company & 0.751 & 0.64 \\
\hline $\begin{array}{l}\text { The most important concern is the good of all the people in the } \\
\text { company }\end{array}$ & 0.632 & \\
\hline \multicolumn{3}{|l|}{ Independent } \\
\hline $\begin{array}{l}\text { In this company, people are expected to follow their own personal } \\
\text { and moral beliefs }\end{array}$ & 0.74 & 0.609 \\
\hline In this company, people are guided by their own personal ethics & 0.596 & \\
\hline $\begin{array}{l}\text { Each person in this company decides for themselves what is right } \\
\text { and wrong }\end{array}$ & 0.688 & \\
\hline
\end{tabular}

\section{Law and code}

In this hospital, the law or ethical code of their profession is the major consideration

In this hospital, people are expected to strictly follow legal or professional standards

People are expected to comply with the law and professional 0.626 standards

over and above other considerations

\section{Rules}

\begin{tabular}{llll}
\hline Successful people in this company go by the book & 0.628 & \\
\hline Successful people in this company strictly obey the company policies & 0.802 & 0.522 \\
\hline $\begin{array}{l}\text { It is very important to follow strictly the companys rules and } \\
\text { procedures here }\end{array}$ & 0.655 & \\
\hline
\end{tabular}

\begin{tabular}{llll}
\hline \multicolumn{1}{c}{ Instrumental } & & \\
\hline People are expected to do anything to further the hospitals interests & 0.892 & \\
\hline $\begin{array}{l}\text { There is no room for ones own personal morals or ethics in this } \\
\text { company }\end{array}$ & 0.814 & 0.719 \\
\hline $\begin{array}{l}\text { In this company, people protect their own interest above other } \\
\text { considerations. }\end{array}$ & 0.703 & \\
\hline
\end{tabular}




\section{Results}

Table 2 shows a matrix of correlation and sample statistics of all variables included in the study. No abnormalities were detected through this matrix - we did find that work experience and age were significantly correlated.

Table 2. Inter-correlations and descriptive statistics

\begin{tabular}{|c|c|c|c|c|c|c|c|c|c|c|c|c|}
\hline & Variables & Mean & SD & 1 & 2 & 3 & 4 & 5 & 6 & 7 & 8 & 9 \\
\hline 1 & Gender & 0.82 & 0.385 & 1 & & & & & & & & \\
\hline 2 & Age & 43.04 & 5.15 & 0.013 & 1 & & & & & & & \\
\hline 3 & $\begin{array}{l}\text { Education } \\
\text { Level }\end{array}$ & 4.24 & 1.342 & 0.035 & -0.007 & 1 & & & & & & \\
\hline 4 & $\begin{array}{l}\text { Work } \\
\text { Experience }\end{array}$ & 25.29 & 6.52 & -0.066 & $0.738 * *$ & -0.002 & 1 & & & & & \\
\hline 5 & Caring & 3.69 & 1.22 & -0.034 & -0.053 & 0.093 & -0.063 & 1 & & & & \\
\hline 6 & Independence & 3.41 & 1.09 & -0.115 & 0.099 & 0.033 & $0.164 *$ & -0.085 & 1 & & & \\
\hline 7 & $\begin{array}{l}\text { Law and } \\
\text { Code }\end{array}$ & 3.71 & 1.18 & 0.063 & -0.049 & -0.053 & 0.008 & $0.045^{*}$ & -0.075 & 1 & & \\
\hline 8 & Rules & 3.57 & 1.12 & -0.025 & $0.005 *$ & 0.091 & -0.017 & -0.003 & 0.087 & -0.014 & 1 & \\
\hline 9 & Instrumental & 3.66 & 1.103 & $0.205 * *$ & 0.136 & -0.039 & 0.037 & $0.161 *$ & -0.103 & 0.007 & 0.026 & 1 \\
\hline 10 & Corruption & 3.517 & 0.97 & 0.073 & 0.08 & 0.002 & 0.048 & 0.066 & 0.061 & 0.132 & $0.144 *$ & -0.04 \\
\hline
\end{tabular}

Table 3 presents the results of the regression. As expected, we found that the control variable of education level had a negative relationship with organizational corruption.

Table 3. Multiple regression results

\begin{tabular}{lccc}
\hline Independent Variable & Beta & $\mathrm{t}$ & Model \\
\hline Dependent variable: Organizational Corruption & & & \\
\hline Gender & 0.049 & 0.69 & \\
\hline Age & -0.021 & -0.198 & \\
\hline Education Level & $-0.132^{* *}$ & -1.874 & R square $=0.087$ \\
\hline Work Experience & 0.082 & 0.789 & F statistics $=2.86$ \\
\hline Caring & $0.111^{*}$ & 1.581 & $p=0.016^{* *}$ \\
\hline Independent & $-0.113^{*}$ & -1.593 & \\
\hline Law and Code & $-0.116^{* *}$ & -1.663 & \\
\hline Rules & -0.074 & -1.073 & \\
\hline Instrumental & $0.159^{* *}$ & 2.259 & \\
\hline
\end{tabular}

Notes: ${ }^{*} p<0.05 ; * *<0.01$. 
All our hypotheses from 1 through 5 were tested using multiple regression analysis. These hypotheses proposed relationships between the different ethical climate types and organizational corruption. As our regression results show us, our regression model was highly statistically significant $(p=0.016)$, and we obtained support for two of our five hypotheses, i.e. hypothesis 1 and hypothesis 4 . Hypothesis 1 proposed that instrumental climates would be positively related with organizational corruption, and hypothesis 4 proposed that law and code climates would be negatively related with organizational corruption. We obtained support for both these contentions. We did not however, obtain any support for hypotheses 3 and 5, i.e. the ones pertaining to independence and rules climates. In terms of hypothesis 2 , we obtained support, albeit in a different direction. We had proposed that caring climates would be negatively related with organizational corruption - however, we found evidence that suggests that caring climates are actually positively related with organizational corruption.

\section{Discussions}

The overarching objective of this study was to explore the relationships between ethical climate types and organizational corruption. Our study found support for two of our hypotheses, and found that another of our hypotheses was supported albeit in an opposite direction from what we had forecasted. In summary, we found that law and code ethical climates were negatively related to organizational corruption, whereas instrumental and caring climates were positively related to organizational corruption.

Our findings are similar to previous research findings to a certain extent - instrumental climates for instance have been found to be consistently associated with a lot of negative outcomes. The self-interest criteria and self-interest promoting behaviors that flourish in egoistic and instrumental climates make it easy to understand why instrumental climates would be positively associated with organizational corruption. In instrumental climates, self-interest values may end up getting internalized by employees. That sort of internalization would then end up having a cascading effect on organizational corruption.

Similarly, our findings in terms of law and code climates having a negative association with organizational corruption can be seen in the context of other research findings, where it was found that law and code climates were associated with positive outcomes. A reduction in corruption can very definitely be considered a positive outcome, and so it is not surprising to see that law and code climates are negatively associated with organizational corruption. Our sample consisted of professionalized workers from hospitals, and it is quite possible that the professional socialization during and after training would have made these employees internalize principled values. Adherence to professional codes is another factor that would help reduce organizational corruption. That in turn would help explain why organizational corruption would be reduced in law and code climates.

However, our findings in terms of caring climates having a positive association with organizational corruption are both unexpected and startling. To our knowledge, ours is the first study that has linked caring climates with a negative organizational outcome. One way of trying to explain this rather surprising result is by considering the key senti- 
ment behind caring climates - the overarching concern for the well-being of others. It is quite possible that if this concern for the well-being of others gets to be overarching and the main raison d'être, then that may end up promoting a culture of corruption, wherein an attitude of 'everyone needs to benefit' ends up getting promoted. This could be one potential explanation for our finding that caring climates are positively associated with organizational corruption.

\section{Conclusions}

We must mention a few limitations of our study and findings - one limitation is that our study was conducted on a Polish sample. Other studies on other national and work contexts must be conducted in order to ensure that our findings are not context dependent. Another potential limitation could be due to common method variance, i.e. the variance attributable to the measurement method rather than the constructs which the measures represent (Tsai, Huang 2008: 578). Method bias is a common source of measurement error, which in turn threatens the validity of the conclusions about relationships between measures (Bagozzi, Yi 1991; Podsakoff et al. 2003; Tsai, Huang 2008). It is possible that this method bias is present in our study, because all our measures were obtained through self-report questionnaires. However, since a questionnaire approach is the only feasible way to collect ethical climate data, and all of the research conducted on ethical climates relies on the questionnaire approach, we believe that our findings are somewhat robust.

In terms of practical implications, our study essentially suggests that organizations and managers invest time to promote principled climates rather than egoistic climates. As a plethora of research evidence suggests, egoistic and instrumental climates have usually been associated with negative organizational outcomes (Martin, Cullen 2006). Managers should try to curtail the growth and flourishing of egoistic cultures which only result in negative and undesirable outcomes. Instead, managers should try and promote principled cultures and behaviors, which would yield in positive and beneficial outcomes. Principled climates, since they espouse explicit and unambiguous rules of employee conduct and expectations, can certainly be very useful in curtailing or reducing corruption. However, in terms of benevolent climates, our findings suggest some sort of balance be exercised with respect to benevolent climates. Perhaps, benevolent climates should be encouraged albeit with some sort of control mechanism, i.e. in combination with principled climates. Our findings suggest that if only benevolent climates exist, then some negative outcomes like organizational corruption could end up getting promoted - it is important that rules and principles be harnessed to combat that.

An interesting area for future research would be to re-examine the link between caring and benevolent climates to organizational outcomes, especially negative outcomes which involve collaboration (such as groupthink, for instance). More research on that front would help resolve whether or not benevolent and caring climates are always desirable climates to cultivate. Similarly, studies aiming to replicate our findings in different national and work contexts too could yield some benefit for furthering the literature base. 


\section{References}

Aguilera, R. V.; Vadera, A. K. 2008. The dark side of authority: antecedents, mechanisms, and outcomes of organizational corruption, Journal of Business Ethics 77(4): 431-449.

http://dx.doi.org/10.1007/s10551-007-9358-8

Ambrose, M. L.; Arnaud, A.; Schminke, M. 2008. Individual moral development and ethical climate: the influence of person-organization fit on job attitudes, Journal of Business Ethics 77(3): 323-333. http://dx.doi.org/10.1007/s10551-007-9352-1

Appelbaum, S. H.; Deguire, K. J.; Lay, M. 2005. The relationship of ethical climate to deviant workplace behavior, Corporate Governance 5(4): 43-55. http://dx.doi.org/10.1108/14720700510616587

Ashforth, B. E.; Anand, V. 2003. The normalization of corruption in organizations, Research in Organizational Behavior 25(3): 1-52. http://dx.doi.org/10.1016/S0191-3085(03)25001-2

Ashforth, B. E.; Gioia, D. A.; Robinson, S. L.; Treviño, L. A. 2008. Re-Viewing Organizational Corruption, Academy of Management Review 33(3): 670-684.

http://dx.doi.org/10.5465/AMR.2008.32465714

Aquino, K.; Becker, T. E. 2005. Lying in negations: how individual and situational factors influence the use of neutralization strategies, Journal of Organizational Behavior 26(6): 661-679. http://dx.doi.org/10.1002/job.332

Apaydin, C.; Balci, A. 2011. Organizational corruption in secondary schools: a focus group study, Education 131(4): 818-829.

Bagozzi, R. P.; Yi, Y. 1991. Multitrait-multimethod matrices in consumer research, Journal of Consumer Research 17(4): 426-439. http://dx.doi.org/10.1086/208568

Balci, A.; Özdemir, M.; Apaydin, C.; Özen, F. 2012. The relationship of organizational corruption with organizational culture, attitude towards work and work ethics: a search on Turkish high school teachers, Asia Pacific Education Review 13(1): 137-146.

http://dx.doi.org/10.1007/s12564-011-9183-8

Bulutlar, F; Öz, E. U. 2009. The effects of ethical climates on bullying behavior in the workplace, Journal of Business Ethics 86(3): 273-295. http://dx.doi.org/10.1007/s10551-008-9847-4

Colvin, G. 2004. The verdict on business: presumed guilty, Fortune November 15: 78.

Cullen, J. B.; Parboteeah, K. P.; Victor, B. 2003. The effects of ethical climates on organizational commitment: a two-study analysis, Journal of Business Ethics 46(2): 127-141.

http://dx.doi.org/10.1023/A:1025089819456

Cullen, J. B.; Victor, B.; Bronson, J. W. 1993. The ethical climate questionnaire: an assessment of its development and validity, Psychological Reports 73(2): 667-674.

http://dx.doi.org/10.2466/pr0.1993.73.2.667

Deshpande, S. P. 1996. Ethical climate and the link between success and ethical behavior: an empirical investigation of a non-profit organization, Journal of Business Ethics 15(3): 315-320. http://dx.doi.org/10.1007/BF00382957

Dumludag, D. 2009. An analysis of the determinants of foreign direct investment in Turkey: the role of the institutional context, Journal of Business Economics and Management 10(1): 15-30. http://dx.doi.org/10.3846/1611-1699.2009.10.15-30

Habib, M.; Zurawicki, L. 2002. Corruption and foreign direct investment, Journal of International Business Studies 33(2): 291-307. http://dx.doi.org/10.1057/palgrave.jibs.8491017

Joseph, J.; Deshpande, S.P. 1997. The impact of ethical climate on job satisfaction of nurses, Health Care Management Review 22(1): 76-81.

Kayes, D. 2006. Organizational corruption as theodicy, Journal of Business Ethics 67(1): 51-62. http://dx.doi.org/10.1007/s10551-006-9004-x 
Koh, H. C.; Boo, E. H. Y. 2001. The link between organizational ethics and job satisfaction: a study of managers in singapore, Journal of Business Ethics 29(4): 309-324.

http://dx.doi.org/10.1023/A:1010741519818

Kohlberg, L. 1984. The psychology of moral development. San Francisco: Harper \& Row.

Liu, A. Fellows, M. M. R.; Ng, J. 2004. Surveyors perspectives on ethics in organizational culture. Engineering, construction and architecture, Management 11(6): 438-449.

http://dx.doi.org/10.1108/09699980410570193

Luo, Y. 2004. An organizational perspective of corruption, Management and Organization Review 1(1): 119-54. http://dx.doi.org/10.1111/j.1740-8784.2004.00006.x

Martin, K. D.; Cullen, J. B. 2006. Continuities and extensions of ethical climate theory: a metaanalytic review, Journal of Business Ethics 69(2): 175-194.

http://dx.doi.org/10.1007/s10551-006-9084-7

Mauro, P. 1995. Corruption and growth, Quarterly Journal of Economics 110(3): 681-712.

http://dx.doi.org/10.2307/2946696

Merton, R. K. 1968. Social theory and structure. New York: Free Press.

Nocera, J. 2002. System failure, Fortune, June 24: 62-66, 68, 70, 72, 74.

Ogrean, C.; Herciu, M.; Belascu, L. 2008. Searching for new paradigms in a globalized world: business ethics as a management strategy, Journal of Business Economics and Management 9(2): 161-165. http://dx.doi.org/10.3846/1611-1699.2008.9.161-165

Pallant, J. 2004. SPSS survival manual. Crows Nest: Allen \& Unwin.

Parboteeah, K. P.; Cullen, J. B.; Victor, B.; Sakano, T. 2005. National culture and ethical climates: a comparison of U.S. and Japanese accounting firms, Management International Review 45(4): 459-481.

Parboteeah, K. P.; Kapp, E. 2008. Ethical climates and safety-enhancing behaviors: an empirical test, Journal of Business Ethics 80(3): 515-529. http://dx.doi.org/10.1007/s10551-007-9452-y

Parboteeah, K. P.; Chen, H. C.; Lin, Y.-T.; Chen, I.-H.; Lee, A. Y.-P.; Chung, A. 2010. Establishing organizational ethical climates: how do managerial practices work?, Journal of Business Ethics 97(4): 596-611. http://dx.doi.org/10.1007/s10551-010-0527-9

Pelletier, K.; Bligh, M. 2008. The aftermath of organizational corruption: employee attributions and emotional reactions, Journal of Business Ethics 80(4): 823-844.

http://dx.doi.org/10.1007/s10551-007-9471-8

Pinto J.; Leana, C. R.; Pil, F. K. 2008. Corrupt organizations or organizations of corrupt individuals? Two types of organization-level corruption, Academy of Management Review 33(3): 685-709. http://dx.doi.org/10.5465/AMR.2008.32465726

Podsakoff, P. M.; MacKenzie, S. B.; Lee, J. Y.; Podsakoff, N. P. 2003. Common method biases in behavioral research: a critical review of the literature and recommended remedies, Journal of Applied Psychology 88(5): 879-903. http://dx.doi.org/10.1037/0021-9010.88.5.879

Rivera-Batiz, F. 2001. International financial liberalization, corruption and economic growth, Review of International Economics 9(4): 727-737. http://dx.doi.org/10.1111/1467-9396.00309

Robertson, C. J.; Watson, A. 2004. Corruption and change: the impact of foreign direct investment, Strategic Management Journal 25(4): 385-396. http://dx.doi.org/10.1002/smj.382

Rodriguez, P.; Uhlenbruk, K.; Eden, L. 2005. Government corruption and the entry strategy of multinationals, Academy of Management Review 30(2): 383-396.

http://dx.doi.org/10.5465/AMR.2005.16387894

Rose-Ackerman, S. 2002, Grand corruption and the ethic of global business, Journal of Banking \& Finance 26(9): 1889-1918. http://dx.doi.org/10.1016/S0378-4266(02)00197-8 
Shleifer, A.; Vishny, R. 1993. Corruption, The Quarterly Journal of Economics 108(3): 599-617. http://dx.doi.org/10.2307/2118402

Shleifer A.; Vishny, R. 1998. The grabbing hand: government pathologies and their cures. Cambridge, MA: Harvard University Press.

Schminke, M.; Ambrose, M. L.; Neubaum, M. L. 2005. The effect of leader moral development on ethical climate anemployee attitudes, Organizational Behavior and Human Decision Processes 97(2): 135-151. http://dx.doi.org/10.1016/j.obhdp.2005.03.006

Sedikides, C.; Brewer, M. B. 2001. Individual self, relational self, collective self. Philadelphia: Psychology Press.

Sherman, L. W. 1980. Three models of organizational corruption in agencies of social control, Social Problems 27(4): 478-491. http://dx.doi.org/10.2307/800176

Simha, A.; Cullen, J. B. 2012. Ethical climates and their effects on organizational outcomes: implications from the past and prophecies for the future, Academy of Management Perspectives 26(4): 20-34. http://dx.doi.org/10.5465/amp.2011.0156

Sims, R. L.; Keon, T. L. 1997. Ethical work climate as a factor in the development of personorganization fit, Journal of Business Ethics 16(11): 1095-1105.

http://dx.doi.org/10.1023/A:1017914502117

Stevens, B. 2008. Corporate ethical codes: effective instruments for influencing behavior, Journal of Business Ethics 78(4): 601-609. http://dx.doi.org/10.1007/s10551-007-9370-z

Stewart, R.; Volpone, S. D.; Avery, D. R.; McKay, P. 2011. You support diversity, but are you ethical? Examining the interactive effects of diversity and ethical climate perceptions on turnover intentions, Journal of Business Ethics 100(4): 581-593. http://dx.doi.org/10.1007/s10551-010-0697-5

Teather, D. 2009. Bernard madoff receives maximum 150 year sentence, The Guardian, 30 June, 2009 [online], [cited 16 October 2011 ]. Available from Internet: http://www.guardian.co.uk/business/2009/jun/29/bernard-madoff-sentence

Theobald, R. 1990. Corruption, development and underdevelopment. Durham: Duke University Press.

Trevino, L. K.; Butterfield, K. D.; Mcabe, K. L. 1998. The ethical context in organizations: influence on employee attitudes and behaviors, Business Ethics Quarterly 8(3): 447-476.

http://dx.doi.org/10.2307/3857431

Tsai, M.-T.; Huang, C.-C. 2008. The relationship among ethical climate types, facets of job satisfaction, and the three components of organizational commitment: a study of nurses in Taiwan, Journal of Business Ethics 80(3): 565-581.

United Nations. 2002. Global Dynamics of Corruption. United Nations Development Programme, Vienna. 33 p.

United Nations. 2008. Tackling Corruption, Transforming Lives. United Nations Development Programme and MacMillan, India. $246 \mathrm{p}$.

Venard, B. 2009. Organizational isomorphism and corruption: an empirical research in Russia, Journal of Business Ethics 89(1): 59-76. http://dx.doi.org/10.1007/s10551-008-9984-9

Victor, B.; Cullen, J. B. 1987. A theory and measure of ethical climate in organizations, in W. C. Fredrick, L. Preston (Eds.). Research in Corporate Social Performance and Policy. London: JAI, 51-71.

Victor, B.; Cullen, J.B. 1988, The organizational bases of ethical work climates, Administrative Science Quarterly 33(1): 101-125. http://dx.doi.org/10.2307/2392857

Voliotis, S. 2011. Abuse of ministerial authority, systemic perjury, and obstruction of justice: corruption in the shadows of organizational practice, Journal of Business Ethics 102(4): 537-562. http://dx.doi.org/10.1007/s10551-011-0826-9 
Waite, D.; Allen, D.2003, Corruption and abuse of power in educational administration, The Urban Review 35(4): 281-296. http://dx.doi.org/10.1023/B:URRE.0000017531.73129.4f

Watkins, S. S. 2003, Ethical conflicts at enron: moral responsibility in corporate capitalism, California Management Review 45(4): 6-19. http://dx.doi.org/10.2307/41166185

Weber, M. [1922] 2002. Economy and society. Berkeley: University of California Press.

Wilson, A. W.; Magarey, A. M.; Mastersson, N. 2008. Reliability and relative validity of a child nutrition questionnaire to simultaneously assess dietary patterns associated with positive energy balance and food behaviors, attitudes, knowledge and environments associated with healthy eating, International Journal of Behavioral Nutrition and Physical Activity 5(5): 1-12.

Wimbush, J. C.; Shepard, J. M. 1994. Toward an understanding of ethical climate: its relationship to ethical behavior and supervisory influence, Journal of Business Ethics 13(8): 637-647. http://dx.doi.org/10.1007/BF00871811

World Bank. 2000. Reforming Public Institutions and Strengthening Governance. Report (November). Public Sector Group, Poverty Reduction and Economic Management Network.

Zukauskas, P.; Vveinhardt, J. 2011. Mobbing diagnosis instrument: stages of construction, structure and connectedness of criteria, Journal of Business Economics and Management 12(2): 400 416. http://dx.doi.org/10.3846/16111699.2011.575193

Agata STACHOWICZ-STANUSCH is an Associate Professor of management at the Silesian University of Technology. She is the head of the Management and Marketing department. She has authored and edited several books in the domains of management education, organizational corruption, and humanistic organizations. She has also published several articles in journals such as the Journal of Business Ethics, Organization and Management, and Journal of Intercultural Management.

Aditya SIMHA is an Assistant Professor of management at the University of Wisconsin - Whitewater. He has research interests in the areas of organizational behavior, business ethics, and entrepreneurship. He has published several articles in journals such as Academy of Management Perspectives, Journal of Business Ethics, Journal of Business Ethics Education, and Journal of Entrepreneurship. 